\title{
Gdje je nestao Pan? (prikaz liječenja paničnog poremećaja s agorafobijom)
}

\author{
1 Sanda Anton \\ 1 Klinika za psihijatriju, KBC Osijek
}

\section{Sažetak}

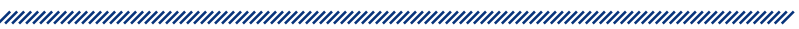

U ovom radu opisan je tvrdokorni slučaj paničnog poremećaja koji je kod bolesnice perzistirao oko deset godina. Cilj je prikazati kognitivno-bihevioralne koncepte na primjeru usklađenoga psihoterapijskog i medikamentoznog liječenja ove bolesnice kojim je došlo do nestanka paničnih ataka, a odsutnost simptoma opservirana je i nakon javljanja tjelesne i životno ugrožavajuće bolesti u obitelji. Povezuje se početak, razvoj i nestanak paničnog poremećaja kroz situaciju životnih događanja uz naglasak na prikazu metoda liječenja i utjecaju egzogenih čimbenika iz životnog miljea bolesnice na ishod bolesti.

Ključne riječi: panični poremećaj, psihoterapija, odnos tjelesnog i psihičkog

Datum primitka: 27.10.2015.

Datum prihvaćanja: 15.03.2016.

Adresa za dopisivanje:

Doc. prim. dr. sc. Sanda Anton, dr. med.

Klinika za psihijatriju

KBC Osijek

Huttlerova 4

31000 Osijek

E-pošta: sanda.anton@os.t-com.hr

Tel.: 091-519-74-66

\section{Uvod}

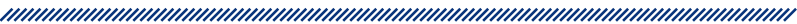

Naziv paničnog poremećaja potječe od priče o grčkom bogu Panu ${ }^{1}$, a najčešće je udružen s agorafobijom. Napadi paničnog straha (epizodne paroksizmalne anksioznosti), nastaju spontano i nisu uvjetovani životno opasnom situacijom ni prisutnošću drugih psihijatrijskih i/ili somatskih poremećaja. Poremećaj je čest, godišnja je prevalencija od $0,6 \%$ do $2,2 \%$, triput je češći kod žena, najčešće se javlja u ranim dvadesetima i na prijelazu tridesetih u četrdesete godine života, ali još uvijek nisu potpuno razjašnjeni mehanizmi njegova nastanka3. Kod ove su patološke anksioznosti kognitivne, emocionalne, fiziološke i ponašajne promjene česte i jake. Klinička slika uključuje epizodičnu paroksizmalnu anksioznost (paniku) uz suhoću usta, lupanje srca, znojenje, drhtanje, osjećaj nedostatka zraka, gušenje, bol u prsima, mučninu, vrtoglavicu, derealizaciju, depersonalizaciju, strah od gubitka kontrole, strah „da će se poludjeti", strah od smrti (obično od infarkta) i parestezije (osjećaj bockanja). Učestalost tih napadaja određuje težinu kliničke slike. U najtežem se obliku napadaji javljaju do četiri puta tjedno, u srednjem obliku najmanje četiri puta mjesečno, a kod najrjeđeg i najlakšeg pore-

1 Pan (grč. Пav) u grčkoj mitologiji bog je pastira, stada, njiva, šuma, polja odnosno „paše i stoke“, njihov zaštitnik i zaštitnik lovaca, stoga ga se naziva i zaštitnikom prirode. Osim toga ljubitelj je glazbe i najbolji plesač među bogovima. Pan je plod ljubavi Hermesa i lijepe nimfe Driope. Rodio se s kozjim nogama, rogat i bradat. Njegov izgled toliko je uplašio njegovu majku da ju je obuzeo dotada nezapamćen strah, pa se takav strah još i danas naziva paničnim strahom. No otac Hermes, obradovao se i prihvatio sina takvog kakav je, uvio ga u zečju kožu te ga poveo sa sobom na Olimp i ponosno ga pokazao bogovima. Na Olimpu su se bogovi toliko smijali i rugali Panovu izgledu da je nesretnik pobjegao u mračne i opasne arkadijske šume ${ }^{1,2}$. 
mećaja javljaju se još rjeđe. Ako je poremećaj udružen s agorafobijom, prisutan je strah od otvorenog prostora, javnih mjesta i prisutnosti mnoštva ljudi, kada se bolesnik ne može brzo skloniti na sigurno mjesto, zbog čega se javlja panična ataka.

Navest ćemo osnovne teorije koje objašnjavaju etiologiju ovog poremećaja.

U nastanku anksioznih poremećaja dokazana je uloga genetskih čimbenika, a važna je i predispozicija osobe za anksiozno reagiranje u stresogenim životnim situacijama. Biologijske teorije anksiozne poremećaje dovode u vezu s poremećajem u neuronskoj komunikaciji i disbalansom ekscitacijskih i inhibicijskih neurotransmitorskih sustava. Kao uzrok panike opisuje se nedovoljnost normalnih mehanizama u središnjem živčanom sustavu koji kontroliraju anksioznost. Važna se uloga pripisuje disfunkciji locusa coeruleusa i noradrenergičnih struktura (tzv. teorija lažnog alarma), kao i nucleusa raphe i serotoninergičnih struktura. Na biologijskom planu, limbički sustav ne pravi razliku između realnog straha i anksioznosti - „evolucija voli anksiozne gene“, tj. bolje je imati lažno pozitivne uzbune jer jedna lažno negativna može ugroziti egzistenciju te je cijena opstanka život u nelagodnoj tjeskobi ${ }^{4}$.

Prema bihevioralnim teorijama, anksioznost je posljedica vezivanja reakcije straha koji se javlja tijekom nekog neugodnog iskustva (bespomoćnosti, straha, panike) uz primarno neutralne stimuluse i proces kondicioniranja (učenje). Operantnim uvjetovanjem uz negativno potkrjepljenje (posljedicu koja slijedi nakon određenog ponašanja kojom se može smanjiti ili povećati vjerojatnost pojavljivanja tog ponašanja) dugoročno se pogoršava poremećaj, npr. bolesnik s agorafobijom izbjegava izlazak iz stana jer je tada smireniji, a time podržava svoj poremećaj.

Izbjegavanje ih dodatno sprječava da nauče kako su simptomi koje doživljavaju bezazleni, a uključuje:

1. promjene u pobuđenosti autonomnoga živčanog sustava kao pripreme za bijeg, borbu ili padanje u nesvijest

2. inhibiciju postojećeg ponašanja

3. selektivno pregledavanje okoline s obzirom na moguće izvore opasnosti ${ }^{5}$.

Prema kognitivnim modelima za javljanje anksioznosti odgovorna su očekivanja ljudi i njihove interpretacije povezane $s$ tjelesnom ili psihosocijalnom opasnošću (misli i predodžbe), uz refleksno aktiviranje „programa postupanja u anksioznosti“, a ne događaji kao takvi (anksioznost je reakcija na netočnu percepciju).

Kognitivne osnove poremećaja prikazuje Clarkov kognitivni model panike iz 1986. godine. Bolesnici su stalno u strepnji i negativnom iščekivanju te pokazuju relativno trajne sklonosti da širok raspon tjelesnih promjena interpretiraju na katastrofičan način. Takve osobe imaju izraženiju anksioznu osjetljivost, tj. sklonije su vjerovanju da određeni tjelesni simptomi mogu imati katastrofalne posljedice. Riječ je o distorzijama na trima razinama procesiranja informacija: perceptivnoj, interpretativnoj i razini pamćenja. Na perceptivnoj razini anksiozne osobe iz mnoštva podražaja probiru moguće prijetnje, na interpretativnoj razini sklone su nejasne podražaje tumačiti kao opasne, a na razini pamćenja sklone su boljem upamćivanju i lakšem dosjećanju anksioznih situacija ${ }^{2}$. Stvarnim ili unutarnjim podražajima dolazi do daljnjeg porasta straha i do fizioloških reakcija (npr. znojenje, lupanje srca...). Bolesnici postaju pretjerano pobuđeni, a unutarnji fokus pažnje omogućava im zamjećivanje osjeta ili promjena kojih mnogi drugi ljudi ne bi bili svjesni. Tjelesne reakcije smatraju se daljnjim dokazom postojanja nekog ozbiljnog tjelesnog ili psihičkog poremećaja što kod bolesnika potiče katastrofiziranje („umrijet ću“) i time se dodatno pojačava simpatička aktivnost i misli („spirala panike“, čime se osoba nalazi u začaranom krugu). Bolesnici ubrzo nauče izbjegavati situacije koje ih dovode u ustrašna stanja, a određeni oblici izbjegavanja potkrepljuju i održavaju bolesnikove negativne interpretacije uz razvijanje "straha od straha“, tj. javljanja bojazni od napadaja.

Psihoanalitičke teorije u osnovi agorafobije nalaze nesvjesni intrapsihički konflikt prededipalnog ili edipalnog tipa koji je u vezi s neprihvatljivim seksualnim ili agresivnim impulsima. Freud je u svojim teorijama podijelio anksioznost na tjeskobu pred realnom opasnošću (nužna je i korisna jer priprema osobu na brzu reakciju) i neurotičnu tjeskobu (nije korisna, djeluje dezorganizirajuće i remeti ponašanje pred opasnošću). O fobiji govori kao o obliku obrane od anksioznosti izazvane potiskivanjem id-impulsa, premještanju zastrašujućeg impulsa ida sa željenog objekta na objekt ili situaciju koja je na neki način povezana s tim impulsom, dok ego izbjegava suočavanje sa stvarnim problemom ili potisnutim konfliktom iz djetinjstva uz razvoj izbjegavanja fobičnih podražaja ${ }^{6}$. Agorafobija se opisuje u vezi s agresivnošću, patološkom simbiozom, separacijskim problemima, odbacujućim roditeljima te zapostavljenošću ili prezaštićenošću u djetinjstvu ${ }^{6-11}$.

Iz literature je razvidno da se u liječenju paničnog poremećaja naglasak stavlja na psihoterapijske postupke, kao najučinkovitije navode se kognitivno-bihevioralne tehnike, uz uporabu anksiolitika i antidepresiva te važnost podrške i uključivanja obitelji u proces liječenja ${ }^{12-20}$. 


\section{Prikaz slučaja}

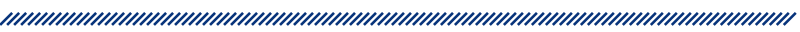

Prikazan je težak slučaj paničnog poremećaja s agorafobijom kod kojeg je liječenje započeto s više godina latencije od početka poremećaja. lako je bolesnica bila u višegodišnjoj kliničkoj opservaciji i raznim terapijskim postupcima kod istog terapeuta, prikaz je detaljnije usmjeren na dio liječenja kognitivno-bihevioralnim tehnikama koji je doveo do nestanka paničnog poremećaja. (Bolesnica je dala pisani pristanak za prikaz svojeg slučaja, op. aut.)

Pri uključivanju u kognitivno-bihevioralni tretman bolesnica je imala 57 godina, bila je udana, majka usvojenog djeteta, kuharica. Hereditet je opterećen psihotičnim procesom po baki s majčine strane koji se ispoljio nakon proživljenoga traumatskog iskustva. U očevoj obitelji više članova bili su potatori. Starija je od dvoje djece u obitelji, a brak roditelja bio je disfunkcionalan, opterećen potusom oca. Završila je srednju ugostiteljsku školu s dobrim uspjehom, nakon godinu dana zaposlila se i udala. Njezin odnos prema majčinstvu obilježen je sterilitetom uz jaku narcističku povredu i doživljaj krivnje. Suprug i ona usvojili su dijete, ali roditeljstvo nije bilo uspješno i rezultiralo je djetetovom ovisnošću o psihoaktivnim tvarima. Bolesnica se opisuje kao agresivnu i dominantnu osobu. Njezina obilježja ličnosti ukazuju na opsesivno-kompulzivnu strukturu ličnosti, jaku ambivalenciju, perfekcionističke crte, krutost i jak doživljaj krivnje. U tjelesnom statusu bila je u višegodišnjem tretmanu neurologa zbog migrenoznih glavobolja, ima alergije na brojne lijekove i sredstva za pranje u domaćinstvu, korove i hranu te je upotrebljavala hormonsku nadomjesnu terapiju zbog menopauze.

\section{Tijek bolesti i liječenja}

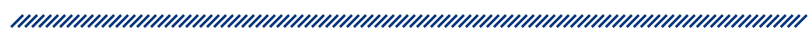

Prvu paničnu ataku doživjela je tijekom Domovinskog rata, uz životnu ugroženost. Iza toga su gotovo svakodnevno uslijedile panične atake. U kliničkoj slici bile su izražene palpitacije, osjećaj nedostatka zraka, profuzna preznojavanja, agorafobija, izlasci samo u pratnji „sigurnosne osobe“, nesanice i glavobolje, uz depresivno raspoloženje, bezvoljnost, anhedoniju i sužavanje socijalnih kontakata.

Liječena je medikamentoznom terapijom (diazepam, bromazepam), a psihijatrijsko liječenje započinje tek nakon deset godina življenja s bolešću. Klinička slika odgo- varala je paničnom poremećaju u komorbiditetu s depresijom. Zbog intenziteta simptoma (visoka anksioznost, atake panike javljaju se oko dvaput tjedno), alergijskih reakcija na brojne alergene i lijekove te uvođenja u psihofarmakoterapiju, uslijedila je prva hospitalizacija. Tada je liječena psihofarmacima (alprazolam, amitriptilin, fluoksetin i nitrazepam) i bila uključena u individualnu i grupnu psihoanalitičku terapiju. Nakon izlaska iz bolnice nastavila je redovito ambulantno psihijatrijsko liječenje, uz anksiolitike i antidepresive. Atake panike bile su reducirane, ali prisutne, a raspoloženje stabilizirano. Nakon četiri godine razboljela joj se majka (precipitirajući čimbenik), a bolesnica se o njoj brinula i time se jako iscrpila, izgubila je osam kilograma, atake panike javljale su se gotovo svakodnevno, bila je depresivna, emocionalno inkontinentna, iz stana je izlazila samo u krugu do pedeset metara, a zbog doživljaja vlastite sigurnosti u pratnji malodobnog djeteta (iracionalno) ili supruga. Učestale panične atake i agorafobija invalidizirali su je te nije mogla odlaziti na radno mjesto iako je ono samo nekoliko ulica udaljeno od njezina stana. Imala je depresivne faze do presuicidalnog nivoa pa je uslijedila hospitalizacija na psihoterapijskom odjelu i tada je uključena u psihoterapijsko liječenje uz kognitivno-bihevioralne tehnike.

Cilj je ovakvog tretmana smanjiti anksioznost bolesnika učeći ga kako će identificirati, procijeniti i modificirati negativne misli povezane s opasnošću i s njima povezana ponašanja. Sadrži zadatke u kojima se traži da bolesnik prikupi informacije i objasni svoju formulaciju poremećaja, a uključuje vođenje dnevnika, protokole za motrenje, popunjavanje standardiziranih upitnika (Beckov upitnik anksioznosti i depresije) te procjene vjerovanja. Terapeut pomaže bolesnicima da dovedu u pitanje svoja iracionalna vjerovanja i pogrešne interpretacije motrenjem identificiranih misli i vjerovanja te procjene vjerovanja u neke anticipirane katastrofe.

Početnom evaluacijom dobiveni su rezultati 35 na Beckovu upitniku depresije (BDI)21, a 43 na Beckovu upitniku anksioznosti (BAI)22 (procjenu je izvršio klinički psiholog). Ciljevi tretmana bili su povezani s izlaskom iz kuće, ugodnim aktivnostima i interpersonalnim odnosima. Bolesnica ih je definirala - ublažiti ili otkloniti znakove bolesti, da se osjeća manje iscrpljeno, da bude zadovoljnija. Ti ciljevi nisu bili konkretizirani te smo ih redefinirali $u$ - naučiti kontrolirati tjelesne simptome anksioznosti, ukloniti anksioznost kao reakciju na tjelesne senzacije, usvojiti vjerovanje da tjelesni simptomi anksioznosti nisu opasni, ukloniti sigurnosna ponašanja, smanjiti strah od ponavljanja ataka panike. Budući da je zbog dugogodišnjega ograničenog izlaženja iz 
kuće izgubila kontakte s prijateljima i socijalno se izolirala, definirala je i cilj angažirati se u više ugodnih i nagrađujućih aktivnosti, obnoviti druženje s prijateljima, a dugoročni je cilj bio spriječiti povrat paničnih ataka.

Tijekom liječenja kod bolesnice je provođena tehnika relaksacije, terapija izlaganjem - sistematska desenzitizacija (u početku u imaginaciji, a kasnije stupnjevanim zadacima izlaganja ustrašnim situacijama) i kognitivna restrukturacija.

U tretman je bio uključen i suprug bolesnice kao sigurnosna osoba. Objašnjeno mu je da je nužna promjena njegova ponašanja, da mora poticati bolesnicu da izlazi sama i ne podržavati njezino bolesno ponašanje. Provođena je relaksacija u sigurnom okruženju, a bolesnica je ispoljavala anksioznost i reagirala simptomima vegetativne pobuđenosti, ali nije odustajala. Baš tu situaciju (kad sjedi kod psihijatra u udobnoj fotelji i osjeća se potpuno sigurno i smireno) odabrala je za sigurnu situaciju koje će se moći sjetiti kada počne osjećati anksioznost te time iznova početi smirivanje. Kroz formu domaćih zadaća vježbala je tu sigurnu sliku uparenu s mislima „osjećam se sigurno“.

Od početka tretmana identificirala je svoje negativne automatske misli i mijenjala ih realnijim mislima (kognitivna restrukturacija). Vodila je dnevnik samopromatranja gdje je bilježila glavne tjelesne senzacije (lupanje srca, ostajanje bez daha, vrtoglavica, osjećaj slabosti), negativne automatske misli koje bi uslijedile nakon tjelesnih senzacija (dobit ću srčani napad, past ću u nesvijest, umrijet ću, a nitko mi neće pomoći) i procjenjivala stupanj vjerovanja u njih na skali od 1 do 100 . Potom je te misli mijenjala realnijim odgovorima, a što je i cilj tehnike kognitivne restrukturacije. Tako je misao da će umrijeti zbog lupanja srca zamijenila racionalnim mislima da je to samo anksioznost, da je to već mnogo puta doživjela i nije umrla, da će to proći te da se možda prebrzo kretala i time izazvala lupanje srca.

Identificirala je svoja temeljna vjerovanja - slaba sam, bezvrijedna sam, loša sam majka, uvijek moram uspjeti, samo si savršen dobar, uvijek moram imati kontrolu nad svime, te posredujuća vjerovanja i pravila - ljudi oko mene (obitelj) bez mene ne mogu živjeti, ni ja bez njih; drugi ljudi (iz okoline) ti nikad neće pomoći; u životu se moram davati preko maksimuma; ako sam savršena, tek onda nešto vrijedim.

U nošenju s poremećajem primjenjivala je ove kompenzacijske strategije: kad počne strah popit ću lijek, pobjeći ću u svoj stan - izbjegavajuće ponašanje (sigurni krug kretanja 50 m od stana), zvat ću supruga da dođe kući s posla (sigurnosna osoba). Kao podržavajući čimbenici definira- ni su: stalna anksioznost, njezine negativne misli, ponašanja bliskih ljudi koji obavljaju sve umjesto nje i održavaju njezino bolesno ponašanje i izbjegavajuće ponašanje te lijekovi koji relativno brzo otklanjaju simptome.

Nakon što je relativno brzo usvojila tehniku relaksacije, započeli smo s tehnikom izlaganja. Tehnika izlaganja počiva na teorijskim postavkama Wolpea da je ustrašno ponašanje naučeno i da se od njega može odučiti i zamijeniti ga prilagođenim, adekvatnijim reakcijama ${ }^{5}$. To se može postići približavanjem umjesto izbjegavanja onog čega se bojimo, tj. „postupnim izlaganjem“. Tretman zahtijeva da bolesnici ponovno dođu u dodir sa stvarima ili situacijama kojih se boje i da ostanu s njima u kontaktu toliko dugo dok se strah ne počne smanjivati, čime se prekida začarani krug i olakšava učenje novih ponašanja. $\mathrm{U}$ periodu liječenja bolesnice u gradu su obnovljene fontane koje su različito udaljene od odjela na kojem je bila hospitalizirana. Odlazila je relaksirana s odjela od bližih do sve udaljenijih fontana uz obvezno vraćanje na odjel i ponavljanje vježbe s istom fontanom nekoliko dana dok se anksioznost ne smanji. U početku se vraćala preznojena, preplavljena, ponekad gotovo bez daha, ali raslo je njezino zadovoljstvo i samopouzdanje, a tjelesne reakcije bivale su manjeg intenziteta, do potpunog gašenja.

Intenzivno psihoterapijsko liječenje provođeno je hospitalno, svakodnevno u ukupnom trajanju mjesec dana (ukupno 25 seansi), a potom je nastavljeno ambulantnim putem suportivnim seansama kroz višegodišnje praćenje. Već na kraju hospitalnog liječenja bila je bez paničnih ataka i izbjegavajućeg ponašanja, bolje raspoložena, uz više samopouzdanja, vrijednosti BDI 15 i BAI 10. Nakon povratka kući ponovno je preuzela aktivnosti povezane s plaćanjem računa i kupovinom, samostalno je izlazila u šetnje i na druženja s prijateljima, nije tražila stalnu prisutnost supruga, bolje je funkcionirala u obitelji i imala manje zahtjeve prema ostalim ukućanima. Ona i suprug evaluirali su liječenje kao vrlo uspješno, sa značajnim utjecajem na poboljšanje njihove zajedničke kvalitete života. S bolesnicom se radilo i na prevenciji povrata simptoma edukacijom, radom na njezinim očekivanjima, postavljanjem realističnih ciljeva te poticanjem prihvaćanja i malih pozitivnih promjena.

Ubrzo nakon toga suprug bolesnice obolio je od karcinoma pluća. Tada se našla u situaciji da ga je trebalo voziti na kemoterapiju, a u tom je trenutku ona bila jedina osoba na koju se on mogao osloniti. Posljednjih osam godina bolesnica nije vozila auto, iako je prije ispoljavanja poremećaja to činila redovito. U početku je izbjegavala vožnju zbog svojih strahova, potom je željela pokušati, ali joj suprug nije dozvolio. Bojala se da će ponovno razviti panične atake, ali to se nije dogodilo. 
Novu je situaciju doživjela kao vitalno ugrožavajuću za svojeg supruga (iako to nije bilo realno), nakon čega je počela voziti auto, nije imala panične atake te se osjećala osnaženo i zadovoljno sobom. Od tada do danas kod bolesnice je povremeno prisutna blaža anksioznost, nema panične atake ni strah od izlaska iz kuće, raspoloženje je stabilizirano, a u farmakoterapiji rijetko upotrebljava niske doze alprazolama. Razne tjelesne bolesti bile su razlog tome što je u međuvremenu umirovljena.

\section{Zaključak}

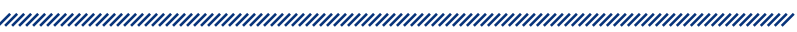

Tijekom dugogodišnjeg liječenja bolesnica je uključena u usklađeno liječenje psihoterapijom i lijekovima. Za ciljeve terapijskog procesa postavili smo ublažiti ili otkloniti znakove bolesti, uspostaviti obiteljsko i socijalno funkcioniranje te spriječiti relaps ili recidiv bolesti. Terapijski postupci uključivali su grupnu i individualnu analitički usmjerenu psihoterapiju, kognitivno-bihevioralnu psihoterapiju (psihoedukaciju, relaksaciju, kognitivnu restrukturaciju i sistemsku desenzitizaciju izlaganjem) i farmakoterapiju, ali liječenje kognitivno-bihevioralnim tehnikama dovelo je do remisije paničnog poremećaja, a time adekvatnijeg funkcioniranja i stabilnoga psihičkog stanja.

Njezinu reakciju djelovanja u kriznoj situaciji (koja se pojavila nakon terapije) bez razvijanja panične atake protumačili smo usvajanjem kompenzacije emocionalnih reakcija na adekvatan način. Obrat u suprotno (od straha do hrabrosti) u njezinom ponašanju bio je pozitivan i poželjan pomak, vidljiv u višegodišnjem stabilnom stanju i izlječenju ranijih simptoma.

\section{Literatura}

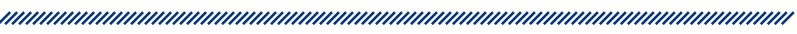

1. Anthon C. A New Classical Dictionary of Greek and Roman Biography, Mythology and Geography, partly based upon The Dictionary of Greek and Roman Biography and Mythology by William Smith. [Internet] Dostupno na: http:// www.columbia.edu/cu/lweb/digital/collections/cul/ texts/ldpd_10482899_000/ldpd_10482899_000.pdf (pristupljeno 25.01.2016.)

2. Pichot P. Panic: attack and disorder. History of the word and concepts. Encephale. 1996; 22 (5): 3-8.

3. Begić D. Psihopatologija. Zagreb: Medicinska naklada; 2011.

4. Cosmides L, Tooby J. Evolutionary Psychology and the Emotions. U: Lewis M. Havilan-Jones JM. Handbook of Emotions. New York: Guilford; 2000: 91-115.
5. Hawton K. Salkovsis PM. Kirk J. Clark DM. Kognitivno-bihevioralna terapija za psihijatrijske probleme. Jastrebarsko: Naklada slap; 2008.

6. Gabbard GO. Psychodynamic Psychiatry in Clinical Practice - The DSM-IV Edition. Washington: American Psychiatric Press; 1994.

7. Compton A. The psychoanalytic view of phobias, Part III: Agoraphobia and other phobias of adults. Psychoanalytic Quaterly. 1992;41:400-425.

8. Meissner WW, Rizzuto AM, Sashin JI, Buie DH. A view of agression in phobic states. Psychoanalytic Quarterly. 1987;56(3):452-476.

9. Sarajlić N. Odraz unutarnjih objektnih odnosa u interpersonalnoj dinamici odraslih. Psihoterapija. 1990;20(1):103-133.

10. Segal $\mathrm{H}$. The paranoid-shizoid position. U: Introduction to the Work of Melanie Klein. London: The Hogart Press and the Institute of Psychoanalysis; 1975.

11. Tošić G, Kajević M. Psychodinamic of phobia. [Internet] Dostupno na: http://www.psihijatrija.com/bibliografija/ radovi/ (pristupljeno 20.09.2015.)

12. Leahy RL, Holland SJ. Treatment Plans and Interventions for Depression and Anxiety Disorders. New York-London: The Guilford Press; 2000.

13. American Psychiatric Association. American Psychiatric Association Practice Guidelines for the Treatment of Psychiatric Disorders: Compendium 2000. Washington D.C: American Psychiatric Association; 2000.

14. Carver CS, Scheier MF. Principles of self-regulation: action and emotion. U: Higgins ET, Sorrentino RM, ur. Handbook of Motivation and Cognition: Foundations of Social Behavior, vol: 2. New York: Gilford; 1990: 3-52.

15. Den Boer JA, ur. Clinical Management of Anxiety. New York: Marcel Dekker, Inc.; 1997.

16. Jakovljević M, Lacković Z i sur. Benzodiazepini u suvremenoj medicini. Zagreb: Medicinska naklada;2001.

17. Otto MW. Deveney C. Cognitive-behavioral therapy and the treatment of panic disorder: efficacy and strategies. The Journal of Clinical Psychiatry. 2005;66(4):28-3.

18. Kampman M. Keijsers GP. Hoogduin CA. Hendriks GJ. A randomized, double-blind, placebo-controlled study of the effects of adjunctive paroxetine in panic disorder patients unsuccessfully treated with cognitive-behavioral therapy alone. The Journal of Clinical Psychiatry. 2002:63(9):772-777.

19. Van Malkolm A. Bakker A. Spinhoven P. Blaauw B. Smeenk S. Ruesnik B. A Meta-Analysis of the Treatment of Panic Disorder with or without Agoraphobia: A Comparison of Psychopharmacological, Cognitive-Behavioral, and Combination Treatments. Journal of Nervous and Mental Disease. 1997;185(8):510-516.

20. Landon TM. Barlow DH. Cognitive-Behavioral Treatment for Panic Disorder: Current Status. Journal of Psychiatric Practice. 2004;10(4):211-226.

21. Beck AT, Steer RA, Brown GK. Beckov inventar depresije BDI-II. Jastrebarsko: Naklada Slap; 2011.

22. Beck AT, Steer RA. Anxiety Inventory Manual. San Antonio, TX: Psychological Corporation; 1993. 


\section{WHERE DID PAN DISAPPEAR? (OVERVIEW OF THE TRETMENT OF PANIC DISORDER WITH AGORAPHOBIA)}

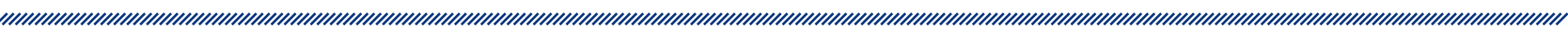

1 Sanda Anton

1 Psychiatric Clinic, University hospital Osijek

\section{Abstract}

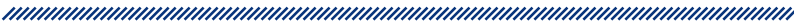

This paper describes a difficult case of a patient with a panic disorder that persisted for ten years. The aim of the paper is to present cognitive-bihevioral concepts on a case of combined psychotherapy and medication treatment which resulted in the disappearance of panic attacks and lack of symptoms, which persisted even after the occurence of a physical and life threatening illnes in the family. This case connects the begining, development and dissapearance of the panic disorder through life events with emphasis on the presentation of the treatment methods and the influence of life events on the illnes outcomes. 